\title{
In The United States Accounting Profession, Will Minorities Make Different Ethical Decisions?
}

Anne J. Rich, Central Connecticut State University, USA Paul H. Mihalek, Central Connecticut State University, USA

\begin{abstract}
The United States has long been referred to as a melting pot. People from all cultures bring to our business world their values and beliefs. For the past two decades, accounting organizations have reached out and supported the education of minorities. Academic research in the area of ethical decision making has attempted to highlight factors that contribute to differences in ethical decision making. Culture, and possibly, religion have been the key variables examined as a basis for differences in an individual's ethical decisions. As more and more minorities enter the profession of accounting in the United States, an important question that should be answered is "Will American minorities approach ethical situations similarly to that of their non-minority American peer group?", or will their cultural backgrounds influence their ethical norms? This paper presents a research study that opens this conversation. As minorities are entering the accounting profession, it is reasonable to expect that Americans from different cultural backgrounds may react differently to ethical dilemmas. However, research on ethical beliefs of minority business and accounting students is rare. The authors developed a survey to determine if there were differences in ethical values based on ethnicity. It was tested using materials provided by KPMG. The survey used a case involving a student lying on his resume. It asked for answers to seven ethical situations and seven activities. The survey was administered in two different major- level accounting classes at a large public university. The results of the study show that minority and non-minority students generally agree on ethical issues and their likely action when a classmate lies on a resume in the process of getting a job. However, there were some interesting differences in the magnitude and direction of the responses by minority and non-minority students. Our findings also suggest that Minority students are more sensitive to ethical transgressions by their peers and feel more negatively impacted if someone lies in the process of getting a job. Accountants are often in a position where they must report violations. Our study suggests students from all backgrounds should engage in discussions about lying and suggest ways to deal with reporting such unethical behavior to authorities.
\end{abstract}

Keywords: Business ethics, accounting ethical dilemmas, ethnicity, minority, non-minority

\section{INTRODUCTION}

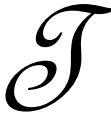

he United States has long been referred to as a melting pot. People from all cultures bring to our business world their values and beliefs. For the past two decades, accounting organizations have reached out and supported the education of minorities. In 2009, the American Institute of Certified Public Accountants (AICPA) celebrated 40 years of dedication to minority initiatives in the accounting profession. Among the organization's numerous programs to support minority initiatives are scholarship programs and leadership workshops. The AICPA is proud that the number of minorities in public accounting is increasing. (AICPA, 2009) The most reliable information about the growth of minorities in the public accounting profession is found in the "AICPA 2009 Trends in the Supply of Accounting Graduates and the Demand for Pubic Accounting Recruits". (AICPA, 2009) Table 1 below shows the percentage of minority and non-minority professionals in CPA firms. 
Except for Asian/Pacific Islanders, it is clear that the Black/African-American and Hispanic/Latino cultures are still clearly underrepresented.

Table 1

Percentage of Minority and Non-Minority Professionals in CPA Firms - 2009

\begin{tabular}{|c|c|c|c|c|c|}
\hline Firm Size & All & $<\mathbf{1 0}$ & $10-49$ & $50-200$ & $>200$ \\
\hline Minority & 17 & 7 & 11 & 12 & 26 \\
\hline Black/American & 3 & 1 & 1 & 2 & 4 \\
\hline Hispanic/Latino & 3 & 2 & 3 & 2 & 4 \\
\hline Asian/Pacific Islander & 10 & 4 & 5 & 7 & 17 \\
\hline American Indian/Alaska Native & 0 & 0 & 0 & 0 & 0 \\
\hline Other & 1 & 0 & 2 & 1 & 1 \\
\hline Non-Minority & 83 & 92 & 85 & 77 & 74 \\
\hline Unknown & 0 & 1 & 4 & 11 & 0 \\
\hline
\end{tabular}

Source: (American Institute of Certified Public Accountants, 2009)

Another professional organization, the National Association of Black Accountants (NABA), has a goal to encourage and assist minority students in entering the accounting profession (National Association of Black Accountants, 2010) The Big 4 accounting firms have reached out to the minority community in order to improve minority representation in their firms. For example, the KMPG Foundation has awarded over $\$ 8.7$ million in scholarships to minorities pursuing doctorate degrees in accounting since 1994 . To date there are 985 minority professors in the United States and an additional 400 currently enrolled in business doctoral programs. (PR Newswire, 2009) (KPMG, 2009) The U.S. Department of Labor, a federal government agency, received a report in May 2008 from the Advisory Committee on the Auditing Profession (ACAP) that recommended improvements in the representation and retention of minorities in the auditing profession to enrich the pool of human capital in the profession. (Clegg, 2008)

The accounting profession has an even longer history in maintaining high ethical standards. Every major professional accounting organization has a code of professional conduct. Educators have been challenged to integrate ethics into the business and accounting curricula. This can be done either through offering a separate ethics course or integrating it throughout the curriculum. All of the large public accounting firms provide teaching materials to assist accounting faculty in discussing accounting ethics in the classroom.

Academic research in the area of ethical decision making has attempted to highlight factors that contribute to differences in ethical decision making. Culture, and possibly, religion have been the key variables examined as a basis for differences in an individual's ethical decisions. However, most of the research on culture has focused on comparing individuals who live in different countries. Much of the research on religion is based on comparing students from religious (private) and public universities. For purposes of this paper however, religion has not been addressed. There has been very little research in the U.S. on how culture affects an individual's response to an ethical dilemma. As more and more minorities enter the profession of accounting in the U. S., an important question that should be answered is "Will American minorities approach ethical situations similarly to their non-minority American peer group?", or "will their cultural backgrounds influence their ethical norms?" This paper presents a research study that opens this conversation.

\section{Ethical Norms and the Impact of Culture and Gender}

As mentioned in the introduction to this paper, accounting has a long and proud history of maintaining high ethical professional standards. While ethics has always been a part of the accounting curriculum, the emphasis on professional ethics is growing and has become a significant learning objective for all college accounting programs. Loeb, 1988 has stated that the main objective of accounting ethics education is to develop students' awareness and 
judgment in ethical issues. In the past, when accounting was a male-dominated, white profession, it was reasonable to conclude that there would be a high degree of consensus among new recruits to the profession when dealing with ethical dilemmas. As women entered the profession, research has shown differences between males and females in some aspects of ethical decision making. (Doty, Tomkiewicz, \& Bass, 2005) Now, however, women are no longer considered a minority group in the accounting profession at least in the United States.

As global factors were introduced into business and accounting programs, researchers expanded their study of business ethics to individuals in other countries. Culture tends to be an enduring trait. (Hofstede, 1991) It is reasonable to expect that cultural differences in ethical decision making will persist among accounting students even after they have substantially completed a degree from a U.S. university. Many studies used Hofstede's pioneering work on culture to explain differences in ethical reasoning by individuals from one country to another. Hofstede's original work was focused on four cultural dimensions (individualism-collectivism, masculinity-femininity, powerdistance, and uncertainty-avoidance). A fifth cultural dimension was later added (long-term vs. short-term orientation). (Hofstede) Just as gender differences were discovered, cultural differences were found when researching individuals in different countries. (Cohen J. L., 2001, Jung, 2009, and Ho, Ho, \& Ho, 2008) In the U.S., differences in ethical reasoning were studied using various multidimensional scales. (Buchan, 2005 and Cohen \& Vennie, 2006 ) Using Mainland Chinese students, Yang and Wu examined a moral intensity construct by asking students their responses to four ethical accounting scenarios. (Yang \& Wu, 2009)

As more minorities enter the accounting profession, it is reasonable to expect that Americans from different cultural backgrounds may react differently to the ethical dilemmas. Research on ethical beliefs of minority business and accounting students is rare. Most universities do not have a sufficient number of minority students in their pool of students. Conversely, in the case of predominantly Black universities, there may be an insufficient pool of nonminority students. Peppas published a study on the attitudes of Hispanics and non-Hispanics in the U.S. While the researcher found there were more similarities than differences between the two groups, nevertheless, his findings reported differences among individuals in terms of what is ethical behavior. (Peppas, 2006 ) Landry et al also looked at the differences in ethical perceptions among Hispanic and non-Hispanic accounting and business students. Their research was based on a questionnaire designed by Cohen et al in 1998. The authors surveyed students at a predominantly Hispanic university and found differences between accounting and business majors in their responses to cases involving various situations. (Landry, Moyes, \& Cortes, 2004 )

Shafer and Park expanded the sample of subjects to include Caucasian, Asian and Hispanic accounting students attending U.S. universities. Students responded to three ethical vignettes. The results provided evidence of significant cultural variations in ethical judgments and self-reported behavioral intentions. The researchers found significant differences between the ethical judgments and intentions of Asian and Caucasian students. The ethical decisions of the Hispanic and Caucasian students did not differ significantly. (Shafer \& Park, 1999)

In prior research on ethical decision-making, the type of dilemma has emerged as a primary factor in differences in student responses. Many of the studies use vignettes to establish the type of ethical dilemma. However, the situation described in the vignettes varies significantly from minor issues to major ethics lapses. McDevitt and Hise have shown that, in ethical situations, materiality does influence the decision process. (McDevitt \& Hise, 2002) Cohen and Vennie demonstrated that a model developed by Jones can help guide accounting ethics research by isolating the contingent factors that affect ethical decision making. They examined how factors differ across different accounting settings. (Cohen \& Vennie, 2006 ) Similarly, Buchan's study looked at personal and contextual factors that influence ethical decisions in the public accounting profession. (Buchan, 2005)

Lopez et al studied the impact of the forces that shaped ethical perceptions. The authors included intranational culture and found significant effects for self-reported intra-national culture. (Lopez, Rechner, \& OlsonBuchanan, 2005 ) Valentine et al found that corporate ethical values signifying different cultural aspects of an ethical context were positively related to person-organization fit. (Valentine, Godkin, \& Lucero, 2002 ) Rodgers and Gago applied a throughput model to cultural and ethical concerns. Their throughput-model approach looked at the importance of how different philosophical perspectives may be used by individuals in arriving at an ethical decision. (Rogers \& Gago, 2001 ) 
The most important finding is that there was a great deal of interchange among undergraduate students that led to a better understanding of differences in all measures examined: wealth, religion, race/ethnicity, immigrant status and politics. Over $40 \%$ of students reported that their understanding of others was often improved through personal interactions with other students who differed from them in terms of socio-economic status, politics, and religion. (Chatman, 2008)

\section{Whistle Blowing and Cheating}

Responses from subjects have been shown to be dependent on the type and severity of the dilemma presented. Academics have studied situations involving whistle blowing and cheating. (Finn, 1995); (Greenberger, Miceli, \& Cohen, 1987 (6) 7); (Loeb \& Cory, 1989 (8) 12); (Miceli \& Near, 1992); and (Near \& Miceli, 1995) Does the educational process contribute to ethical behavior? Brody and Bowman (1998) indicated that individuals are often worried about personal ramifications when involved in a potential whistle-blowing decision. Smith and Davis used cheating by students as an indicator of future ethical business behavior. (Smyth \& Davis, 2009) Their research included questions involved with falsifying information on a job application. Overall, regardless of class status (freshman through senior) or the religious affiliation of their schools, students recognized lying on a job application was unethical.

\section{OUR STUDY}

In Fall 2009, students at Central Connecticut State University (CCSU), a large state university in Connecticut, were surveyed to determine whether minority and non-minority accounting students differ in their responses to an ethical dilemma involved with whistle blowing and cheating. In 2009, CCSU has over 12,000 students, of whom approximately $48 \%$ are male and $52 \%$ are female. The following table captures the racial demographics associated with the entire undergraduate population for 2009:

Table 2

CCSU 2009 Undergraduate Population by Race

\begin{tabular}{|l|c|}
\hline \multicolumn{1}{|c|}{ Group Represented } & \% of total undergraduates \\
\hline Black, non Hispanic & 8.3 \\
\hline American Indian & 0.4 \\
\hline Asian/Pacific Islander & 3.0 \\
\hline Hispanic & 6.7 \\
\hline White, non Hispanic & 73.0 \\
\hline Non-resident Aliens & 1.3 \\
\hline Unknown & 7.3 \\
\hline
\end{tabular}

Source: (Central Connecticut State University, 2010)

\section{Our Sample}

Students in two courses in the accounting program were surveyed. The first course was AC 300, Foundations of Accounting, which is primarily a course for juniors and is the first required course in the accounting major. A small number of finance majors select this course as an elective. The second course was AC 445, Auditing, which is primarily a course for seniors and is usually taken only by accounting majors. The number of students completing the survey is summarized in Table 3. Demographic information is included in Tables 4a through $4 \mathrm{~d}$.

Table 3

Students Surveyed by Course

Fall 2009

\begin{tabular}{|c|c|c|c|}
\hline Course & Non-Minority & Minority & Total \\
\hline AC 300 & $66(71 \%)$ & $27(29 \%)$ & 93 \\
\hline AC 445 & $29(67 \%)$ & $14(33 \%)$ & 43 \\
\hline Total & $95(70 \%)$ & $41(30 \%)$ & 136 \\
\hline
\end{tabular}


Tables 4a through 4d

Demographic Information

\begin{tabular}{|c|c|c|c|c|}
\hline & & Minority & Non-Minority & Total \\
\hline Age & $18-22$ & 16 & 55 & 71 \\
\hline & $23-28$ & 15 & 25 & 40 \\
\hline Total & $29+$ & 10 & 15 & 25 \\
\hline
\end{tabular}

\begin{tabular}{|c|c|c|c|c|}
\hline & & Minority & Non-Minority & Total \\
\hline Male/Female & Male & 20 & 48 & 68 \\
\hline Total & Female & 21 & 47 & 68 \\
\hline
\end{tabular}

\begin{tabular}{|c|c|c|c|c|}
\hline & & Minority & Non-Minority & Total \\
\hline Born in U.S. & Yes & 19 & 80 & 99 \\
\hline Total & No & 22 & 15 & 37 \\
\hline
\end{tabular}

\begin{tabular}{|c|c|c|c|c|}
\hline & & Minority & Non-Minority & Total \\
\hline \multirow{2}{*}{$\begin{array}{c}\text { Speak Foreign } \\
\text { Language }\end{array}$} & Yes & 21 & 21 & 42 \\
\cline { 2 - 5 } & No & 19 & 74 & 93 \\
\hline Total & & 40 & 95 & 135 \\
\hline
\end{tabular}

\section{THE ETHICAL DILEMMA AND THE SURVEY INSTRUMENT}

Public accounting firms provide academics with numerous case studies depicting ethical dilemmas to use in the classroom setting. KPMG provides several on their website. (KPMG, 2009) The Internship is a case study that describes two interns from the same school being hired by an accounting firm. One student lied on his resume. This ethical dilemma was selected for discussion because it is a situation that could actually happen to the students in the study. KMPG provides instructors with resources to encourage discussion and heighten awareness to sensitive issues. These resources include seven elements in reviewing the ethical issues and seven alternative courses of action. These seven ethical issues and seven alternative actions serve as the basis for the questions posed to the students. The following chart describes the seven ethical issues in the case and seven possible alternative actions the students could take to deal with the situation:

\begin{tabular}{|ll|}
\hline & \multicolumn{1}{c|}{ Ethical Issues: } \\
\hline 1. & Is Jack preventing a more qualified person from getting his job? \\
\hline 2. & Silence gives consent- Is Jack an accomplice if he doesn't answer honestly? \\
\hline 3. & Is it ethical to lie on a resume for an internship? \\
\hline 4. & Is Jack betraying Matthew if he brings the information to the recruiter? \\
\hline 5. & Does Jack have a certain amount of loyalty to the firm? \\
\hline 6. & Does Jack have a loyalty to the university that would compel him to report Matthew's lies? \\
\hline 7. & Does Jack have a responsibility to be loyal to Matthew?
\end{tabular}

\begin{tabular}{|cl|}
\hline & \multicolumn{1}{c|}{ Alternative Actions: Jack can- } \\
\hline 1. & Avoid the situation and say nothing \\
\hline 2. & Confront Matthew and ask him to admit his deception \\
\hline 3. & Inform the recruiter of Matt's exaggerations \\
\hline 4. & Tell other classmates about Matthew's lies \\
\hline 5. & Report Matthew anonymously to the university \\
\hline 6. & Report Matthew anonymously to the company \\
\hline 7. & Inform the company of Matthew's dishonesty revealing your own identity \\
\hline
\end{tabular}


The case and the questionnaire are found in Appendices 1 and 2 respectively. During class, students were given a brief case to read. Then the questionnaire was distributed to obtain demographic information. After reading the case, students were asked how they would react to the seven ethical issues questions assuming first that the individual who cheated was from the same ethnic background as the student himself. They were asked how likely they would handle the situation and given seven possible alternatives. Then student was then asked to repeat his or her responses assuming the individual who cheated was from a different ethnic background. After the student completed these sections of the survey, students then discussed the case in small groups. Students were then asked what the group consensus was and whether or not the student changed his or her mind about how to handle the situation. Only one case was used due to the time-consuming nature of the discussions.

\section{THE RESULTS}

The responses of the students were recorded using SPSS and EXCEL. The following tables report the results of the mean responses capturing differences to the seven ethical issues between minority students and their non-minority counterparts. Tables 5 and 7 summarize the responses when students were informed that Jack was from the same ethnic background. Tables 6 and 8 summarize the responses when students were informed that Jack was from a different ethnic background than they were.

Table 5

Mean Reponses by Minority and Non-Minority Students to Review of the Ethical Issues When Jack Was from the Same Ethnic Background as Respondent

Possible Responses were (1) Yes, (1.5) Don't know, (3) No

\begin{tabular}{|l|c|c|c|c|c|c|c|}
\hline Ethical Situation & 1 & 2 & 3 & 4 & 5 & 6 & 7 \\
\hline Minority & 1.59 & 1.41 & 1.95 & 1.78 & 1.16 & 1.29 & 1.87 \\
\hline Non-Minority & 1.38 & 1.34 & 1.93 & 1.72 & 1.18 & 1.41 & 1.77 \\
\hline
\end{tabular}

Table 6

Mean Reponses by Minority and Non-Minority Students to Review of the Ethical Issues When Jack Was from a Different Ethnic Background than the Respondent Possible Responses were (1) Yes, (1.5) Don't know (3) No

\begin{tabular}{|l|c|c|c|c|c|c|c|}
\hline Ethical Situation & 1 & 2 & 3 & 4 & 5 & 6 & 7 \\
\hline Minority & 1.56 & 1.38 & 1.93 & 1.82 & 1.17 & 1.45 & 1.84 \\
\hline Non-Minority & 1.38 & 1.35 & 1.91 & 1.73 & 1.16 & 1.60 & 1.96 \\
\hline
\end{tabular}

Table 7

Mean Reponses by Minority and Non-Minority Students to Review of the Alternative Actions When Jack Was from the Same Ethnic Background as Respondent

Possible Responses were (1) Definitely not likely, (2) Somewhat not likely, (3) Not sure, (4) Somewhat likely and (5)

\begin{tabular}{|c|c|c|c|c|c|c|c|}
\hline \multicolumn{8}{|c|}{ Definitely would do } \\
\hline Alternative Actions & 1 & 2 & 3 & 4 & 5 & 6 & 7 \\
\hline Minority & 2.63 & 3.49 & 2.76 & 1.78 & 3.10 & 3.24 & 2.48 \\
\hline Non-Minority & 2.65 & 3.53 & 3.22 & 2.26 & 3.02 & 3.36 & 2.43 \\
\hline
\end{tabular}

Table 8

Mean Reponses by Minority and Non-Minority Students to Review of the Alternative Actions When Jack Was from a Different Ethnic Background as Respondent

Possible Responses were (1) Definitely not likely, (2) Somewhat not likely, (3) Not sure, (4) Somewhat likely and (5)

\begin{tabular}{|l|c|c|c|c|c|c|c|}
\hline Dthical Situation & 1 & 2 & 3 & 4 & 5 & 6 & 7 \\
\hline Minority & 2.71 & 3.61 & 2.95 & 1.71 & 3.10 & 3.12 & 2.30 \\
\hline Non-Minority & 2.72 & 3.45 & 3.20 & 2.33 & 3.00 & 3.34 & 2.38 \\
\hline
\end{tabular}




\section{Analysis of Results}

Students were asked if the actions of the intern were ethical and were required to respond to seven questions. A response of 1 would indicate student agreement with the statement (YES), a response of 2 would indicate most the respondents disagree (NO), and a response of 1.5 would indicate the students did not know what the student should do. Looking at Table 5, the mean response by the students to a review of the ethical issues when the case involved another student from the same ethnic background, there was agreement by all students to ethical issues 2, 3, 4, and 5. All students agreed that lying is unethical (question 3) and the individual does have some any loyalty to the firm that is hiring him (question 5). In addition, there was general agreement that the student who was the one who did not lie on his resume is giving his consent by remaining silent (question 2). Students generally agreed it is not a betrayal of a liar if the individual is reported to the recruiter (question 4). However, on the issue of whether or not the student has a loyalty to the university (question 6), minority students felt somewhat stronger about being able to bring the liar to the university's attention than the non-minority students when the liar is from the same ethnic background. Another large difference in the mean responses of the students is found in question 7. Minority students felt more strongly that they do not have a responsibility to be loyal to the liar (question 7). The most significant difference is found in students' responses to question 1. Non-minority students were significantly less likely to believe the liar was preventing a more qualified person from getting the job than their minority counterparts. From Table 6, we see the results did not substantially change for six of the seven ethical issues when students were asked to respond from the perspective of the other student being from a different ethnic background. Again, the most significant difference was found for the issue relating to whether or not the liar prevented a more qualified person from getting the job. Only for question 7 did the results change in direction of which group felt stronger. We still see that both minority and non-minority students felt they have no loyalty to the liar, but when the liar was from a different ethnic background, the feelings were stronger by the non-minority group.

Students were also asked how likely they would respond by a specific action. Students' responses were evaluated on a scale of 1 to 5. A response of 1 indicated that students would definitely not engage in that activity while a response of 5 indicated they would definitely engage in that action. Looking at Table 7, the mean response by the students to how likely they would take a particular action indicated that there was agreement by all students that the most likely action would be to confront Matthew and ask him to admit his deception (alternative 2). The next likely action would be to report the perpetrator to the firm anonymously (alternative 6) and report the perpetrator anonymously to the university (alternative 5). The least likely alternative action that all students agreed on was confronting the individual (alternative 1) and informing the firm of the perpetrator's dishonesty revealing the student's own identity (alternative 7). However, a difference between minority and non-minority students is found in their responses to whether or not they would avoid the situation. Non-minority students were more likely to avoid the situation (a mean score of 2.76) compared to minority students (a mean score of 3.22). Another difference is the students' responses to telling classmates. Minority students were less likely to share this information with others (a mean score of 1.78) compared to non-minority students (a mean score of 2.26). Table 8 shows the mean responses by minority and non-minority students when the perpetrator is from a different ethnic background. There are similar agreements and differences, with one exception. Minority students indicated they would more likely than their nonminority counterparts inform the recruiter of the perpetrator's exaggerations.

\section{Discussion}

The population of the city in which our university is located includes many families from different ethnic backgrounds. Our students are mostly commuters. The majority of them were educated in public schools which exposed them to students from various multi-cultural backgrounds. As a result, there has been continuous interaction among minority and non-minority students. While we expected to see more differences between these two groups, it was a pleasant discovery that our students did not differentiate in their responses when asked how they would treat their peer based on ethnic background. During the discussion period in class students suggested their responses may be impacted if the liar was their friend. It appeared students feel loyalty to their close friends. In addition, the discussion led more students to acknowledge they would likely report the liar anonymously.

The results of the study show that minority and non-minority students generally agree on ethical issues and their likely action when a classmate lies on a resume in the process of getting a job. However, there were some 
interesting differences in the magnitude and direction of the responses by minority and non-minority students. Dealing with ethical issues, we found the largest difference was in the perceptions of our students to whether or not the liar is preventing a more qualified person from getting the job. The minority students felt much stronger than the non-minority students that the liar was preventing a more qualified person from getting the job. We believe that minority students may be more sensitive to the difficulties of getting a professional job. The students' ethnic background also had an impact in their sense of loyalty to the university. Minority students felt a stronger sense of loyalty to the university than their non-minority counterparts. Our findings suggest that minority students are more sensitive to ethical transgressions by their peers and feel more negatively impacted if someone lies in the process of getting a job.

Based on the responses to the actions students are likely to take in dealing with this particular dilemma, we see both groups are in agreement about trying to avoid the situation and not talk about the individual with their classmates. Both groups initially did not consider reporting the individual anonymously, but after discussions indicated they might consider this action. Both groups indicated their most likely action would be to confront the liar and ask him to admit his deception. However, in discussions, this only occurred if the individual was a friend. Students of all backgrounds are hesitant to expose the liar yet they understand lying is wrong. Non-minority students were slightly more likely to report the transgressor to the recruiter than their non-minority counterparts. It also appears non-minority students were slightly more likely to report transgressions when the individual was from a different ethnic background. Minority students have shown have stronger feelings that the liar is preventing a more qualified applicant from getting the job and their responses suggest they are less comfortable in reporting the individual to a recruiter, the company, or to the university compared to their non-minority counterparts.

Accountants are often in a position where they must report violations. Our study suggests students from all backgrounds should engage in discussions about lying and suggest ways to deal with reporting such unethical behavior to authorities. Corporate and professional codes of ethical conduct, such as the Institute of Management Accountants' (IMA's) Statement of Ethical Professional Practice, would help students identify possible alternatives. The results of this research study have implications for handling ethics training in both the classroom and in practice. (Institute of Management Accountants)

\section{Limitations of the Study}

The authors recognize that, as with most of the research efforts in ethical dilemmas, there is a social desirability bias toward giving the perceived right answer. This may have been heightened since the students were in an ethnically mixed classroom and the assignment included a discussion with their classmates.

There are two major limitations to this study. The first is that only one case was used. The case was selected to be one that the respondents could actually experience as students. Only approximately thirty minutes was devoted to the case discussion. The results may have been different if more cases were selected or if the case situation was different.

The second major limitation is that students at only one university were included in the study. The majority of students at CCSU has been educated at integrated schools and lives in integrated communities. Results may be different when students at predominantly minority or non-minority schools are surveyed.

\section{Areas for Future Research}

While there was little difference in the responses of the subjects due to minority/non-minority status, there were differences in their responses to the question posed. Future research should explore the factors that contributed to these differences. For example, the number of years the student has been in the United States may be an important factor. In addition, future research should explore the impact of students learning in multi-cultural environments as compared to homogeneous groups. 


\section{CONCLUSION}

Pless and Maak note that in management theory and in business practice, dealing with diversity plays a dominant role. (Pless \& Maak, 2004) However, many companies are disappointed in their lack of progress in achieving the desired results. The authors suggest diversity is essentially about cultural norms and values. Business enterprises should create an inclusive work environment. The same can be said about the classroom. Our experience shows that ethnic background did not play a difference in the students' reactions to this ethical dilemma. We believe our students' extensive experience in their multi-cultural education explains our results. Research by Phillips supports this result. Phillips examined how surface-level diversity, based on ethnicity, and deep-level similarities influenced three-person decision-making groups. When groups were given the opportunity to learn about their deeplevel similarities prior to a task, group members felt more similar to one another and reported greater perceived attraction. Her research has implications for managing diversity in the workplace as well as for educators introducing ethical dilemmas in the classroom. (Phillips, 2006)

When a university does not have a diverse student body, faculty could utilize case studies and books to heighten awareness of minorities in the accounting profession. The book, "A White-Collar Profession" chronicles the path of Black accountants in the U.S. Samson et al who studied the impact of assigning this book to their students suggest it presents an opportunity for all educators to communicate how accountants from different ethnic backgrounds have been treated in the past. (Samson, Allen, Fleischman, \& Robinson, 2006) Faculty wishing to integrate diversity into their classrooms will find an excellent resource for relevant articles on diversity at the Fisher College of Business. (Fisher College of Business Diversity Bibliography, 2009)

\section{AUTHOR INFORMATION}

Anne Rich is a Professor Accounting at Central Connecticut State University. She holds a BA, MBA and Ph.D. degree in accounting. She is a Certified Public Accountant in Connecticut and is a Certified Management Accountant. She teaches intermediate accounting course. Anne's research interests are international accounting with a particular emphasis on China. She has also written articles on active learning, distance learning and cross-cultural ethics. She is a member of the Connecticut Society of CPAs, the American Accounting Association and the Institute of Management Accountants.

Paul Mihalek is a Professor of Accounting at Central Connecticut State University. He received his BA, MBA, and $\mathrm{Ph} . D$. from the University of Connecticut. He is a Certified Public Accountant in Connecticut and Maryland. He teaches Principles of Financial Accounting, Auditing, and the First Year Experience Course. He has worked for the GAO, KPMG, Arthur Andersen, and the Travelers. Paul's research areas of interest are active learning and crosscultural ethics. He is a member of the Connecticut Society of CPAs. He currently chairs the Innovations in Accounting Education Committee of the American Accounting Association's Teaching and Learning Section.

\section{REFERENCES}

1. American Institute of Certified Public Accountants. (2009). 2009 Trends in the Supply of Accounting Graduates and the Demand in Public Accounting Recruits. NJ: AICPA.

2. Brody, R. G., \& Bowman, L. (1998 (32) 4). Accounting and Psychology Students' Perceptions of Whistleblowing. College Student Journal .

3. Buchan, H. F. (2005 (61) 2). Ethical Decision Making in the Public Accounting Profession: An Extension of Ajzen's Theory of Planned Behavior. Journal of Business Ethics , 165-181.

4. Central Connecticut State University. (2010, 2 1). Retrieved 2 1, 2010, from CCSU: http://www.ccsu.edu/uploaded/departments/AdministrativeDepartments/Institutional_Research_and_Asses sment/Fact_Book/2009-10/Headcount_Enrollment/Fall_GenderRace.pdf

5. $\quad$ Clegg, R. (2008, June 5). Accounting for Preferences. National Review Online .

6. Cohen, J. L. (2001 (30) 4). An Examination of Differences in Ethical Decision-Making Between Canadian Business Students and Accounting Professionals. Journal of Business Ethics, 319-338.

7. Cohen, J. R., \& Vennie, N. M. (2006 (1)). The Applicability of a Contingent-Factors Model to Accounting Ethics Research. Journal of Business Ethics , 1-18. 
8. Doty, E., Tomkiewicz, J., \& Bass, K. (2005, 39 (4)). Sex Differences in Motivational Traits and Ethical Decision Making Among Graduating Accounting Majors. College Student Journal.

9. Fisher College of Business Diversity Bibliography. (2009, 11 20). Retrieved 11 20, 2009, from Fisher College of Business Diversity Bibliography: http://fisher.osu.eud/offices/diversity/diversitresources/diversity-bibliography

10. Greenberger, D. M. (1987 (6) 7). Oppositionists and Group Norms: The Reciprocal Influence of Whistle Blowers and Co-Workers. Journal of Business Ethics , 527-543.

11. Ho, C.-Y. L.-H., Ho, C. L., \& Ho, Y. H. (2008 (36(9)). An Examination of Cultural Differences in Ethical Decision Making Using the Multidimensional Ethics Scale. Social Behavior and Personality, 1213-.

12. Hofstede, G. (n.d.). Geert Hofstede Resources. Retrieved 02 15, 2010, from Geert Hofstede.com: http://www.geert hofstede.com/geert hofstede resources.html

13. Jung, I. (2009 (53) 3). Ethical Judgments and Behaviors: Applying a Multidimensional Ethics Scale to Measuring ICT Ethics of College Students. Computers and Education, 940-949.

14. KPMG. (2009, 08 03). us.kpmg.com. Retrieved 02 03, 2010, from http://www.us.kpmg.com

15. Landry, R., Moyes, G., \& Cortes, A. (2004 (Nov/Dec)). Ethical Perceptions Among Hispanic Students: Differences by Major and Gender. Journal of Education for Business, 102-2xx.

16. Loeb, S. E., \& Cory, S. N. (1989 (8) 12). Whistle Blowing and Management Accounting. Journal of Business Ethics , 903-916.

17. Lopez, Y., Rechner, P., \& Olson-Buchanan, J. B. (2005 (60) 4). Shaping Ethical Perceptions: An Empirical Asessment of the Influence of Business Education: Culture and Demographic Factors. Journal of Business Ethics, 341-358.

18. McDevitt, R., \& Hise, J. V. (2002 (40) 3). Influences in Ethical Dilemmas Is Increasing Intensity. Journal of Business Ethics , 261-274.

19. National Association of Black Accountants. (2010, February 1). http://www.nabainc.org/AboutNABA/tabid/294/Default.aspx. Retrieved February 1, 2010, from National Association of Black Accountants: http://www.nabainc.org/AboutNABA/tabid/294/Default.aspx

20. Peppas, S. (2006 (26) 3). Attitudes of Hispanics and Non-Hispanics in the U.S.: A Comparative Study of Business Ethics. Management Research News, 92-105.

21. Phillips, K. (2006 (9) 4). Surface-Level Diversity and Decision-Making in Groups: When Does Deep-Level Similarity Help? Group Processes and Intergroup Relations , 467-.

22. Pless, N. M., \& Maak, T. (2004 (54) 2). Building an Inclusive Diversity Culture: Principles, Processes and Practice. Journal of Business Ethics , 129-147.

23. PR Newswire. (2009, 08). PRNewswire. Retrieved 02 03, 2010, from PRNewswire: http://www.prnewswire.com/news-releases/kpmg-foundation-marks-15th-year-of-minority-accountingdoctoral-scholarship-program-with-awards-of-390000-to-scholars-62119632.html

24. Rogers, R., \& Gago, S. (2001 (31) 4). Cultural and Ethical Effects on Managerial Decisions: Examined in a Throughput Model. Journal of Business Ethics, 355-367.

25. Samson, W. D., Allen, C., Fleischman, R., \& Robinson, I. (2006). Using A White Collar Profession in Accounting Courses: Approaches to Addressing Diversity. Accounting Historians Journal .

26. Shafer, W. E., \& Park, J. (1999). An Empirical Investigation of Cultural Differences in Ethical Decision Making Among U.S. Accounting Students. Journal of Education for Business , 220-224.

27. Simga-Mugan, C., Daly, B. A., Onkal, D., \& Kavut, L. (2005 (57) 2). The Influence of Nationality and Gender on Ethical Sensitivity: An Application of the Issue-Contiingent Model. Journal of Business Ethcis , 139-159.

28. Smyth, L., \& Davis, J. R. (2009 (March/April)). Students' Perceptions of Business Ethics: Using Cheating as a Surrogate for Business Situations. Journal of Education for Business , 229-239.

29. Steve Chatman. (2008). Does Diversity Matter in the Educational Process? Berkeley, paper CSHE 5.08 found at http:cshe.berkeley.edu: Center for Studies in Higher Education, University of California.

30. Thorne, L., \& Saunders, S. B. (2002 (35) 1). The Socio-Cultural Embeddedness of Individuals; Ethical Reasoning in Organizations (Cross-Cultural Ethics). Journal of Business Ethics , 1-14.

31. Valentine, S., Godkin, L., \& Lucero, M. (2002 (41) 4). Ethical Context, Organizational Commitment, and Person-Organization Fit. Journal of Business Ethics, 349-360.

32. Yang, H. L., \& Wu, W. P. (2009 (38) 3). The Effect of Moral Intensity of Ethical Decision Making in Accounting. Journal of Moral Education , 335-351. 


\section{APPENDIX 1: THE CASE}

\section{The Internship}

Jack was just hired as a new summer intern for ABCD, LLP - a large international accounting firm. Some of his classmates have also accepted summer intern positions in this organization.

During orientation, the names and biographies of other summer interns were distributed to all new hires. Jack noticed that Matthew Smith, one of his classmates who worked with Jack last summer at a local accounting company had been hired too. When reviewing Matthew's information, Jack noticed several significant discrepancies. Matthew appeared to have used a great deal of creative license in reporting his accomplishments. Not only did Matthew exaggerate about the responsibilities he held for Beta Alpha Psi - the National Financial Honor Society, he had completely fabricated some of his work experiences at their mutual previous employer.

ABCD, LLP, like most other companies, has thorough reference checks for full-time positions but not for summer internships. The recruiting manager asked Jack if he was looking forward to working with Matthew again this summer.

\section{What should Jack do?}

\section{APPENDIX 2: THE QUESTIONNAIRE}

So that I can get a picture of the diversity of those taking this survey, please take a minute to answer the following questions about how you identify (check all that apply):

1. What is your racial background? Circle One

$\begin{array}{llll}\text { African } & & \text { Middle Eastern } & \text { White } \\ \text { Asian } & \mp & \text { Mixed } & \text { If your self-identification } \\ \text { Black } & \mp & \text { Native American } & \text { is not listed, please inform me: }\end{array}$

Caribbean Native Hawaiian

European Eastern Pacific Islander

European Western

Latino South Asian

2. From which specific country did you or your parents/grandparents come from?

3. Were you born in the United States? Yes No

If no, how many years have you been in the U.S?

4. Do you speak a foreign language fluently? Yes No

If yes, which language?

5. What is your socio-economic background? Circle one

Working Class Upper Class

Middle Class If your self-identification is not listed, please

Upper-Middle Class inform me:

6. What is your sex/gender? Circle One

Female $\quad \mp$ Male

7. Your status at CCSU: (Circle all that apply)

Part-time Full-time

Junior Senior Graduate student

Accounting major Finance major other major
8. Your age: $18-22$ $23-28$ $29+$

At this point, please read the case and without discussing your answers, respond to the following questions. Be honest with your responses! 


\section{IF MATTHEW WAS FROM THE SAME ETHIC BACKGROUND AS YOURSELF:}

\begin{tabular}{|l|l|l|l|}
\hline & Yes & No & $\begin{array}{c}\text { Don't know/not } \\
\text { sure }\end{array}$ \\
\hline $\begin{array}{l}\text { 1. Do you believe that Jack is preventing a more } \\
\text { qualified person from getting the job? }\end{array}$ & & & \\
\hline $\begin{array}{l}\text { 2. Silence gives consent - Is Jack an accomplice if he } \\
\text { doesn't answer honestly? }\end{array}$ & & & \\
\hline 3. Is it ethical to lie on a resume for an internship? & & & \\
\hline $\begin{array}{l}\text { 4, Is Jack betraying Matthew if he brings the } \\
\text { information to the recruiter? }\end{array}$ & & & \\
\hline $\begin{array}{l}\text { 5. Does Jack have a certain amount of loyalty to the } \\
\text { firm? }\end{array}$ & & & \\
\hline $\begin{array}{l}\text { 6. Does Jack have loyalty to the university that would } \\
\text { compel him to report Matthew's lies? }\end{array}$ & & & \\
\hline $\begin{array}{l}\text { 7. Does Jack have a responsibility to be loyal to } \\
\text { Matthew? }\end{array}$ & & & \\
\hline
\end{tabular}

If you were Jack, how likely are you to ? (answer honestly)

\begin{tabular}{|l|l|l|l|l|l|}
\hline $\begin{array}{l}\text { Avoid the situation and } \\
\text { say nothing }\end{array}$ & $\begin{array}{c}\text { Definitely not } \\
\text { likely }\end{array}$ & $\begin{array}{c}\text { Somewhat not } \\
\text { likely }\end{array}$ & Not sure & $\begin{array}{c}\text { Somewhat } \\
\text { likely }\end{array}$ & $\begin{array}{c}\text { Definitely } \\
\text { would do }\end{array}$ \\
\hline $\begin{array}{l}\text { Confront Matthew and } \\
\text { ask him to admit his } \\
\text { deception }\end{array}$ & & & & \\
\hline $\begin{array}{l}\text { Inform the recruiter of } \\
\text { Matt's exaggerations }\end{array}$ & & & & & \\
\hline $\begin{array}{l}\text { Tell other classmates } \\
\text { about Matthew's lies }\end{array}$ & & & & & \\
\hline $\begin{array}{l}\text { Report Matthew } \\
\text { anonymously to the } \\
\text { university }\end{array}$ & & & & & \\
\hline $\begin{array}{l}\text { Report Matthew } \\
\text { anonymously to the } \\
\text { company }\end{array}$ & & & & & \\
\hline $\begin{array}{l}\text { Inform the company of } \\
\text { Matthew's dishonesty } \\
\text { revealing your own } \\
\text { identity }\end{array}$ & & & & & \\
\hline
\end{tabular}




\section{IF MATTHEW WAS FROM A DIFFERENT ETHIC BACKGROUND FROM YOURSELF:}

\begin{tabular}{|l|l|l|l|}
\hline & Yes & No & $\begin{array}{c}\text { Don't know/not } \\
\text { sure }\end{array}$ \\
\hline $\begin{array}{l}\text { 1. Do you believe that Jack is preventing a more } \\
\text { qualified person from getting the job? }\end{array}$ & & & \\
\hline $\begin{array}{l}\text { 2. Silence gives consent - Is Jack an accomplice if he } \\
\text { doesn't answer honestly? }\end{array}$ & & & \\
\hline 3. Is it ethical to lie on a resume for an internship? & & & \\
\hline $\begin{array}{l}\text { 4, Is Jack betraying Matthew if he brings the } \\
\text { information to the recruiter? }\end{array}$ & & & \\
\hline $\begin{array}{l}\text { 5. Does Jack have a certain amount of loyalty to the } \\
\text { firm? }\end{array}$ & & & \\
\hline $\begin{array}{l}\text { 6. Does Jack have loyalty to the university that would } \\
\text { compel him to report Matthew's lies? }\end{array}$ & & & \\
\hline $\begin{array}{l}\text { 7. Does Jack have a responsibility to be loyal to } \\
\text { Matthew? }\end{array}$ & & & \\
\hline
\end{tabular}

If you were Jack, how likely are you to ? (answer honestly)

\begin{tabular}{|l|l|l|l|l|l|}
\hline $\begin{array}{l}\text { Avoid the situation and } \\
\text { say nothing }\end{array}$ & $\begin{array}{c}\text { Definitely not } \\
\text { likely }\end{array}$ & $\begin{array}{c}\text { Somewhat not } \\
\text { likely }\end{array}$ & Not sure & $\begin{array}{c}\text { Somewhat } \\
\text { likely }\end{array}$ & $\begin{array}{c}\text { Definitely } \\
\text { would do }\end{array}$ \\
\hline $\begin{array}{l}\text { Confront Matthew and } \\
\text { ask him to admit his } \\
\text { deception }\end{array}$ & & & & \\
\hline $\begin{array}{l}\text { Inform the recruiter of } \\
\text { Matt's exaggerations }\end{array}$ & & & & & \\
\hline $\begin{array}{l}\text { Tell other classmates } \\
\text { about Matthew's lies }\end{array}$ & & & & & \\
\hline $\begin{array}{l}\text { Report Matthew } \\
\text { anonymously to the } \\
\text { university }\end{array}$ & & & & & \\
\hline $\begin{array}{l}\text { Report Matthew } \\
\text { anonymously to the } \\
\text { company }\end{array}$ & & & & & \\
\hline $\begin{array}{l}\text { Inform the company of } \\
\text { Matthew's dishonesty } \\
\text { revealing your own } \\
\text { identity }\end{array}$ & & & & & \\
\hline
\end{tabular}

Now you can discuss the case with your classmates 
After discussing the case with your classmates, please answer the following questions again:

If you were Jack, how likely are you to ? (answer honestly)

\begin{tabular}{|l|l|l|l|l|l|}
\hline & $\begin{array}{c}\text { Definitely not } \\
\text { likely }\end{array}$ & $\begin{array}{c}\text { Somewhat not } \\
\text { likely }\end{array}$ & Not sure & $\begin{array}{c}\text { Somewhat } \\
\text { likely }\end{array}$ & $\begin{array}{c}\text { Definitely } \\
\text { would do }\end{array}$ \\
\hline $\begin{array}{l}\text { Avoid the situation and } \\
\text { say nothing }\end{array}$ & & & & \\
\hline $\begin{array}{l}\text { Confront Matthew and } \\
\text { ask him to admit his } \\
\text { deception }\end{array}$ & & & & \\
\hline $\begin{array}{l}\text { Inform the recruiter of } \\
\text { Matt's exaggerations }\end{array}$ & & & & & \\
\hline $\begin{array}{l}\text { Tell other classmates } \\
\text { about Matthew's lies }\end{array}$ & & & & \\
\hline $\begin{array}{l}\text { Report Matthew } \\
\text { anonymously to the } \\
\text { university }\end{array}$ & & & & \\
\hline $\begin{array}{l}\text { Report Matthew } \\
\text { anonymously to the } \\
\text { company }\end{array}$ & & & & & \\
\hline $\begin{array}{l}\text { Inform the company of } \\
\text { Matthew's dishonesty } \\
\text { revealing your own } \\
\text { identity }\end{array}$ & & & & & \\
\hline
\end{tabular}

Did you change your mind about any of your responses? Yes No

If yes, can you explain why you changed your mind?

NOTES 